\title{
James Ebdon
}

University of Brighton

Brighton, United Kingdom

\section{Huw Taylor}

University of Brighton

Brighton, United Kingdom

\section{Sarah Purnell}

University of Brighton

Brighton, United Kingdom 


\section{Copyright:}

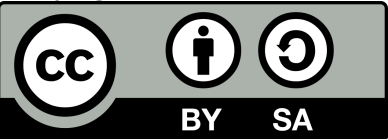

This publication is available in Open Access under the Attribution-ShareAlike 3.0 IGO (CC-BY-SA 3.0 IGO) license (http://creativecommons.org/licenses/by-sa/3.0/igo). By using the content of this publication, the users accept to be bound by the terms of use of the UNESCO Open Access Repository (http://www.unesco.org/openaccess/terms-use-ccbysa-en).

\section{Disclaimer:}

The designations employed and the presentation of material throughout this publication do not imply the expression of any opinion whatsoever on the part of UNESCO concerning the legal status of any country, territory, city or area or of its authorities, or concerning the delimitation of its frontiers or boundaries. The ideas and opinions expressed in this publication are those of the authors; they are not necessarily those of UNESCO and do not commit the Organization.

\section{Citation:}

Peres, M.R., Edbon, J., Purnell, S. and Taylor, H. 2019. Risk assessment of sanitation, water supply and hygiene in rural Brasil. In: J.B. Rose and B. Jiménez-Cisneros, (eds) Global Water Pathogen Project. http://www.waterpathogens.org (S. Petterson and G. Medema (eds) Part 5 Case Studies) http://www.waterpathogens.org/book/risk-assessment-of-sanitation-water-supply-and-hygiene-in-rural-Brasil. Michigan State University, E. Lansing, MI, UNESCO. https://doi.org/10.14321/waterpathogens.47

Acknowledgements: K.R.L. Young, Project Design editor; Website Design: Agroknow (http://www.agroknow.com)

Last published: July 24, 2019 


\section{Summary}

\section{Highlights}

- Health risks from excreta-borne pathogens come from may exposure routes in rural Brazil

- A tiered approach was developed for a holistic assessment of the risk via sanitation, drinking water and hygiene

- Excreta-borne exposure pathways have a high crosscontamination potential in the domestic environment

- Hand-to-mouth and drinking water both posed a relatively high risk of infection (by Salmonella spp., Giardia lamblia and norovirus)

- Raising awareness of the important (crosscontaminating) exposure pathways may improve the health in these communities

\section{Graphical abstract}

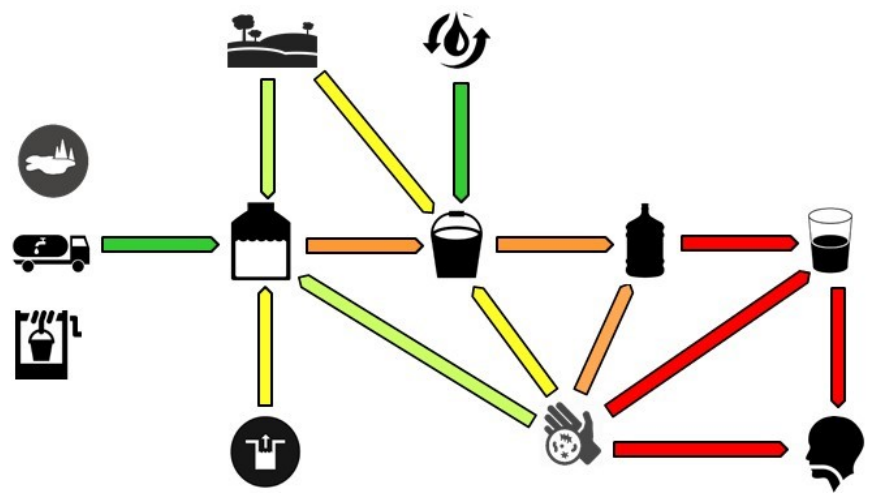

\section{Introduction}

People living in rural communities located in the semiarid region of North East Brazil, face several health issues, common to those living in many other low-income communities around the globe. Water scarcity, combined with lack of awareness about the need for 'safe' handling, storage of drinking water and poor hygiene appear to contribute significantly to the microbial contamination of water from source-to-mouth. Contamination may occur at several critical-points within the domestic environment within these communities. Understanding the contribution of the different routes of exposure is necessary to support effective risk management. The consumption of drinking water containing pathogens can lead to numerous diarrheal diseases and is one of the leading causes of childhood mortality and morbidity in the world (WHO, 2017). The following case study illustrates how a tiered approach to Quantitative Microbial Risk Assessment (QMRA) can be applied to provide objective information with which to identify priority areas for risk management of multi-sourced rural water supply systems.

\section{Problem formulation}

The purpose of the QMRA was to provide an evidencebase for effective management of the health risk associated with the different water contamination routes in this rural community. The specific risk assessment objective was to:

- Assess the risk of infection posed by multi-source drinking water supplies and hand-to-mouth routes to the population living in rural communities in the semi-arid Sertao region of North East Brazil.

The scope of the study was defined by the following steps:

Hazard identification: Norovirus, Salmonella spp. and Giardia lamblia were selected in this assessment because these pathogens presented higher prevalence levels in feces of patients with symptomatic and asymptomatic diarrheal infections in rural Brazil. It is important to mention that both Salmonella spp. and Giardia lamblia can also be shed and spread by several domestic and wild animals, which were also common in the rural settings studied. All selected pathogens presented high health significance and moderate-to-long persistence in water supplies.

Exposure pathways: Drinking water originated from multiple sources, including tankered water (from both surface water and groundwater sources), rainwater, and desalinated water (groundwater), which was stored in water storage reservoirs (cistern) and/or within household drinking water storage containers. Treated (as reported by residents) and untreated waters were also evaluated during the study.

Health outcomes: Annual probability of infection.

\section{Exposure assessment}

Information relating to the water supply system, sanitation and hygiene was gathered through questionnaires, which were conducted face-to-face with the residents. Sanitary surveys were also conducted during the field survey. Data provided by the Brazilian health authorities, as well as from the literature were also used during the formulation of the exposure assessments. A monitoring program was also developed to quantify the level of fecal contamination through the detection and enumeration of $E$. coli. Figure 1 illustrates the conceptual scenario model developed, including the water, microbial and ingestion routes identified in this study. 


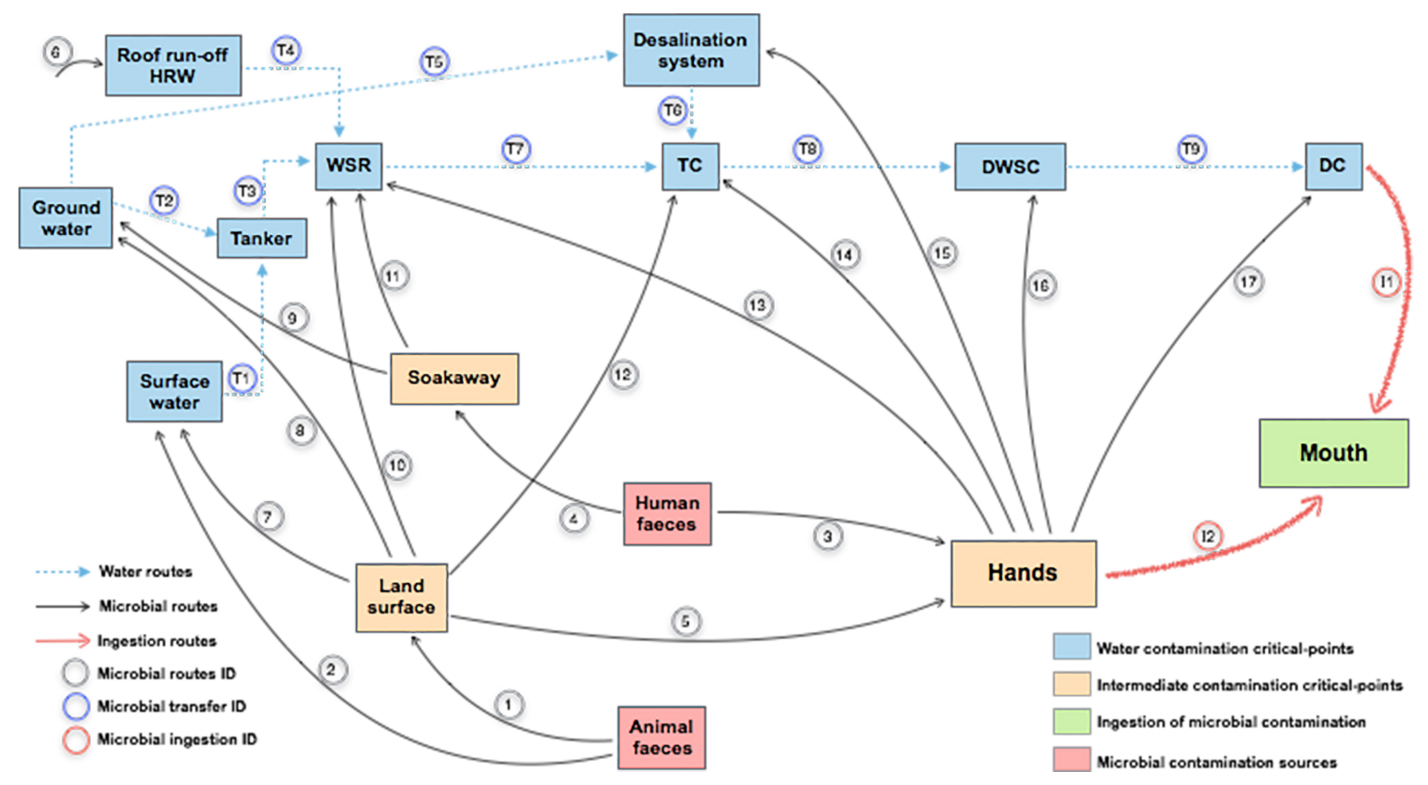

WSR $=$ water storage reservoir; $\mathrm{TC}=$ transport container; $\mathrm{DWSC}=$ in-house drinking water storage container; DC =drinking container.

Figure 1. Conceptual model for the microbial transmission pathways associated with drinking water and hand-to-mouth exposure routes in rural communities for QMRA.

\subsection{Drinking water (I1) and hand-to-mouth (I2) exposure}

The exposure dose for the drinking waters (I1) from different sources was estimated based on E. coli concentrations, and was described with triangular distributions (Table 1). The first and third quartiles of $E$. coli counts observed at each step of the water supply chain (origin, water storage reservoir and in-house drinking water storage container) were used to represent the minimum and maximum values, whereas the median was assumed to be the mode of the distribution. For the hand-to-mouth route (I2), a triangular probability density function (PDF) was created for the microbial load on both hands, based on a study undertaken by Pickering et al.,(2010).

Table 1. Probability Density Functions (PDF) to represent E. coli levels on hands and in water within water storage reservoirs and household drinking water storage containers

\begin{tabular}{lc}
\hline $\begin{array}{l}\text { Water Quality at Different Stages } \\
\text { of the Water Supply Chain }\end{array}$ & PDF Parameters \\
\hline Hands & $(3.5 ; 309 ; 3162)(\mathrm{CFU})$ \\
HRRW at WSR & $(1 ; 10 ; 42.5)(\mathrm{CFU} / 100 \mathrm{~mL}), \mathrm{n}=59$ \\
TW at WSR & $(6.5 ; 31 ; 194)(\mathrm{CFU} / 100 \mathrm{~mL}), \mathrm{n}=35$ \\
HRRW + TW at WSR*1 & $(3 ; 5 ; 31)(\mathrm{CFU} / 100 \mathrm{~mL}), \mathrm{n}=25$ \\
HRRW + TW at WSR*2 & $(1 ; 10 ; 37)(\mathrm{CFU} / 100 \mathrm{~mL}), \mathrm{n}=21$ \\
HRRW + TW at WSR*3 & $(2 ; 10 ; 51)(\mathrm{CFU} / 100 \mathrm{~mL}), \mathrm{n}=17$ \\
DW at DWSC & $(1 ; 9 ; 79.5)(\mathrm{CFU} / 100 \mathrm{~mL}), \mathrm{n}=12$ \\
HRRW at DWSC & $(1.75 ; 6.5 ; 35)(\mathrm{CFU} / 100 \mathrm{~mL}), \mathrm{n}=20$ \\
TW at DWSC & $(3 ; 14 ; 24)(\mathrm{CFU} / 100 \mathrm{~mL}), \mathrm{n}=5$ \\
HRRW + TW at DWSC*1 & $(2 ; 8 ; 34)(\mathrm{CFU} / 100 \mathrm{~mL}), \mathrm{n}=25$ \\
HRRW + TW at DWSC*2 & $(1 ; 4 ; 29)(\mathrm{CFU} / 100 \mathrm{~mL}), \mathrm{n}=21$ \\
HRRW + TW at DWSC*3 & $(1 ; 1 ; 1)(\mathrm{CFU} / 100 \mathrm{~mL}), \mathrm{n}=17$
\end{tabular}

${ }^{\mathrm{a}} \mathrm{CFU}=$ Colony Forming Unit; ${ }^{\mathrm{b}} \mathrm{DW}=$ Desalinated Water; HRRW = Harvested Roof run-off Rain Water; TW = Tankered Water; WSR = Water Storage Reservoir; DWSC = in-house Drinking Water Storage Container. 
These E.coli concentrations were translated to concentrations of the target pathogens in the different drinking waters and on hands by the formulas and data described in the annex.

\subsection{Intake and dose}

In the household, hygiene during taking of water from the storage container to drink (microbial pathways 17 and T9) were considered to contribute to the microbial contamination of drinking containers, and therefore, to the final ingestion dose through the drinking water route. Most of research in the literature reported that the mean intake of water per person varies between 1.10 and 1.50 liters per day (Williams et al., 2001). However, a higher volume was adopted in this study because it was expected that people in the semi-arid region would drink more water. Moreovers,

based on the fact that people normally drink water at various intervals throughout the day and the contamination of drinking containers (DC) was considered in this assessment, the risk of infection was based on the ingested dose per event rather than the daily intake of water. The ingestion dose for the drinking water and the hand-tomouth routes were estimated based on the formulas 1 and 2 , respectively.

$$
I D(T P)=\left(C T P_{D W S C} \times V_{D C} \div 100\right)+N T P_{\text {hands }} \times P M C_{H a n d s-D C}(1)
$$

ID (TP) = ingestion dose of a certain target pathogen (n); $\mathrm{CTP}_{\mathrm{DWsC}}=$ concentration of target pathogens at the inhouse drinking water storage container; $\mathrm{NTP}_{\text {Hands }}=$ number of target pathogens on hands (n/two hands); $\mathrm{PMC}_{\text {Hands-DC }}=$ proportion of microorganisms' contribution from hands to drinking containers (\%).

The number of hand-to-mouth touching events per day was assumed to be ten, based on the findings of a recent research undertaken in rural Accra, Ghana (Antwi-Agyei et al., 2016). However, another triangular PDF was created to include uncertainty on the daily number of events that someone consumes water in this analysis. This PDF was assumed to have a minimum of one, maximum of ten and mode of six events per day.

$$
I D(T P)=N T P_{\text {Hands }} \times P T P T E_{\text {Hands-mouth }} \times P T T P T_{\text {Hands-mouth }}
$$

ID (TP) = ingestion dose of a certain target pathogen (n); $\mathrm{NTP}_{\text {Hands }}=$ number of target pathogens on hands (n/two hands); PTPTE $_{\text {Hands-mouth }}=$ proportion of target pathogens transferred per event; PTTPT $_{\text {Hands-mouth }}=$ Percentage of times that hands transfer target pathogens to the mouth.

\section{Health effects assessment}

A Beta-Poisson model was used to assess risk posed by Salmonella spp. and norovirus, whereas risk of infection posed by Giardia lamblia was performed using the exponential dose-response model. The dose-response models and their respective parameters were adopted from the Centre for Advancing Microbial Risk Assessment (CAMRA, 2015), and are summarized in Table 2. 
Table 2. Selected parameters for dose-response models

\begin{tabular}{|c|c|c|c|c|c|c|}
\hline Host type & Agent Strain & Route & Best Fit Model & Optimized Parameter(s) & LD50/ ID50 ${ }^{\mathrm{a}}$ & Reference \\
\hline Mice & $\begin{array}{c}\text { Salmonella } \\
\text { meleagridis } \\
\text { strain I }\end{array}$ & Oral & Beta-Poisson & $\alpha^{b}=3.89 \mathrm{E}-01, \mathrm{~N} 50=1.68 \mathrm{E}+04$ & $1.68 \mathrm{E}+04$ & $\begin{array}{c}\text { McCullough } \\
\text { and Eisele, } \\
1951\end{array}$ \\
\hline Human & Norovirus & Oral & Beta-Poisson & $\alpha=1.11 \mathrm{E}-01, \mathrm{~N} 50=1.70 \mathrm{E}+04$ & $1.70 \mathrm{E}+04$ & $\begin{array}{l}\text { Leak et al., } \\
\quad 2011\end{array}$ \\
\hline Human & $\begin{array}{c}\text { Giardia } \\
\text { lamblia from } \\
\text { an infected } \\
\text { human }\end{array}$ & Oral & Exponential & $\mathrm{K}^{\mathrm{C}}=1.99 \mathrm{E}-02$ & $3.48 \mathrm{E}+01$ & $\begin{array}{l}\text { Rendtorff, } \\
1953\end{array}$ \\
\hline
\end{tabular}

${ }^{\mathrm{a}}$ LD50/ID50 = Lethal Dose 50 / Infectious Dose $50=$ The amount of microorganisms that is sufficient to kill $50 \%$ of a population; ${ }^{\mathrm{b}} \alpha=$ parameters of the beta-Poisson distribution; ${ }^{\mathrm{c}} \mathrm{K}=$ survival probability, N50

\section{Risk characterization}

The probability of infection per person per year was stochastically estimated by combining the ingestion dose for each scenario variant with the dose-response model and performing simulations with 10,000 iterations using the Latin hypercube sampling technique.

The risk assessment applied to all water sources identified in the rural communities, considering the proportional volume of use of each source, resulted in a high risk of infection for all TP: Salmonella spp. $\left(4.0 \times 10^{-2}\right)$, Giardia lamblia $\left(6.2 \times 10^{-2}\right)$ and norovirus (one), compared to the maximum level of risk $\left(10^{-4}\right)$ suggested by the US-EPA guidelines. The hand-to-mouth route was observed to pose a slightly lower risk compared with the drinking water route for Salmonella spp. $\left(1.1 \times 10^{-2}\right)$, Giardia lamblia (3.7 x $\left.10^{-2}\right)$ and norovirus $\left(8.0 \times 10^{-1}\right)$, but still represented a significant level of risk to human health.

The assessment of the three most used water sources for drinking (desalinated water, harvested roof run-off rainwater and tankered water) indicated a moderate to high risk for all microorganisms assessed in this study (as shown in Table 3). Unexpectedly, desalinated water presented higher risk for both Salmonella spp. and Giardia lamblia compared to harvested roof run-off rainwater (HRRW) and tankered water (TW). This was very likely caused by the inadequate transportation, handling and storage of drinking water.

Table 3. Median annual risk of infection per person for the population consuming the various available water sources in the rural communities studied

\begin{tabular}{lccc}
\hline Target Pathogen Desalinated Water Users & Harvested Roof Run-Off Rainwater Users & Tankered Water Users \\
\hline Salmonella spp. & $7.3 \mathrm{E}-02$ & $5.1 \mathrm{E}-02$ & $6.8 \mathrm{E}-02$ \\
Giardia lamblia & $2.7 \mathrm{E}-02$ & $1.9 \mathrm{E}-02$ & $2.2 \mathrm{E}-02$ \\
Norovirus & 1 & $9.9 \mathrm{E}-01$ & 1
\end{tabular}


The risk assessment of the different types of drinking water treatment (reported by consumers) showed that consumers using ceramic candle filters had a significantly lower risk of infection by Giardia lamblia and a slightly lower risk for both Salmonella spp. and norovirus, when compared to users consuming non-treated or chlorinated water (Table 4). Although it was expected that Salmonella spp. and norovirus would be removed more effectively by chlorination compared to ceramic filtration, it was observed that users that reported to use chlorine tablets to treat their drinking water prior consumption were inadequately applying it (or not using it at all), mainly because of taste and/or odour issues.

Table 4. Median annual risk of infection per person for the population consuming non-treated and treated (chlorination and filtration) drinking water in the rural communities studied

\begin{tabular}{lccc}
\hline \multicolumn{1}{c}{ Target Pathogen } & Non-Treated Water Users & Chlorinated Water Users & Filtered Water Users \\
Salmonella spp. & $5.4 \mathrm{E}-02$ & $4.7 \mathrm{E}-02$ & $2.5 \mathrm{E}-02$ \\
Giardia lamblia & $2.0 \mathrm{E}-02$ & $1.7 \mathrm{E}-02$ & $8.1 \mathrm{E}-03$ \\
Norovirus & 1 & $9.9 \mathrm{E}-01$ & $9.7 \mathrm{E}-01$
\end{tabular}

\section{Risk management}

The QMRA outcomes were very helpful for identifying the most useful and appropriate risk management strategies for use within the rural communities in semi-arid regions of Brazil. The high risk of infection (especially for norovirus) observed in this study, even in desalinated water stored within the drinking water container showed that microbial contamination was happening at the household level and that was nullifying the effect of water treatment. So more effort should be directed towards raising awareness among local inhabitants with regards to water, sanitation and hygiene issues within the domestic environment.

It was also recommended that the use of ceramic candle filters should be promoted because of their high level of social acceptability, observed efficacy in reducing microbial contamination of drinking water and consequently in reducing the risk of diarrheal disease. Moreover, it was recommended that these filters should include an activated carbon component to enhance the social acceptability of a previous chlorination step within the water storage reservoir. Finally, the study also suggested that the Brazilian health authorities need to do more to direct efforts to raise awareness and educate local residents with respect to water, sanitation and hygiene.

\section{Evaluation of the QMRA}

The approach to risk assessment performed in this study provided valuable quantitative information to suggest that rural populations living in the semi-arid region of North East Brazil were at a high risk of infection by locally relevant pathogens, independently of the water source used. This assessment showed that even desalinated water can be highly contaminated by the time it reaches the drinking water storage container, and therefore, that the transportation, handling and storage of drinking water should be done carefully and safely. Finally, the QMRA approach adopted here helped facilitate understanding of a complex water supply system, in which consumers often received water from multiple sources. 


\section{Annex I. Estimating pathogen concentrations in different water sources}

A. Pathogen and E. coli excretion by human and animal sources

Formulas F1, F2, F3 and F4 were used to estimate the daily contribution of E. coli and target pathogens in various sources of contamination and are presented below:

a. Animals other than humans (cat, cattle, chicken, dog, goat, pig, pigeon and sheep)

Number of E. coli excreted per day $=$ number of $E$. coli excreted per gramme of faeces $x$ daily excreted mass of faeces $x$ estimated population

Number of TP excreted per day = number of pathogen excreted per gramme of faeces $x$ daily excreted mass of faeces $x$ estimated population

b. Humans

Number of E. coli excreted per year $=$ number of $E$. coli excreted per gramme of faeces $x$ daily excreted mass of faeces $x$ estimated population of communities $\times 365$ days

Note: The number of organisms excreted per year assumes that people defecate a daily average amount of feces with constant concentration of E. coli.

For the estimation of the number of pathogens excreted per year, the incidence of diarrheal diseases in the municipalities containing the rural communities was combined with the prevalence of the pathogens among diarrheal cases to estimate the number of diarrheal diseases caused by each pathogen investigated. As the number of cases, especially in low-income countries is normally considered to be underreported (Cairncross et al., 2010 ), this case study considered that only $25 \%$ of diarrheal cases were reported. The number of asymptomatic infections was also considered and was estimated by multiplying the prevalence of asymptomatic infection and the population not presenting symptomatic infection and was considered constant throughout the year.

Number of pathogen excreted per year $=$ (number of pathogen excreted per gramme of faeces $x$ number of symptomatic infection in a year $x$ daily excreted mass of faeces $x$ number of days that pathogen is excreted since infection began) + (number of pathogen excreted per gramme of faeces $x$ number of asymptomatic infection in a year $x$ daily excreted mass of faeces $\times$ (365 - shedding time following infection)

B. Microbial load from land surfaces and roofs

The reported amount of precipitation over twenty-four hours was divided into ranges of days with precipitation events, to estimate the microbial load contribution from land surfaces to water storage reservoirs and from roof run-off to cisterns, as this contribution is heavily dependent on the number of rainfall events associated with its intensity. An exponential decay model $\left(C_{f}=C_{i} \times e^{-k t}\right)$ was used to estimate the decay of microorganisms in many critical-points along the water supply system. A summary of the formulas and assumptions used to estimate the number of E. coli and target pathogens in intermediate cross-contamination critical-points and water sources is presented in Table A1 and A2, respectively. 
Table A1. Formulas to estimate the number of $E$. coli and target pathogens in intermediate crosscontamination critical-points water sources

\begin{tabular}{|c|c|c|}
\hline $\begin{array}{l}\text { Intermediate Cross- } \\
\text { Contamination }\end{array}$ & Formula $^{a}$ & Unit \\
\hline $\begin{array}{l}\text { Land surface } \\
\qquad \text { (LS1) }\end{array}$ & $D I N M_{L S 1}=\left(\sum_{n=1}^{9}\left(P A D_{L S 1_{n}} \times N M E D_{n}\right)\right) \div A C$ & $\mathrm{CFU} / \mathrm{m}^{2}$ \\
\hline $\begin{array}{l}\text { Land surface } \\
\qquad(\text { LS2) }\end{array}$ & $D I N M_{L S 2}=\left(\sum_{n=1}^{9}\left(P A D_{L S 2_{n}} \times N M E D_{n}\right)\right.$ & CFU \\
\hline Soakaways & $D I N M_{S K}=\left(\sum_{n=1}^{9}\left(P A D_{S K_{n}} \times N M E D_{n}\right) \div\left(N o H \times P H_{S K}\right)\right) \times R F_{S K I}$ & CFU/system \\
\hline Hands & $\begin{aligned} & N T P_{\text {Hands }}=N E C_{\text {Hands }} \times R F_{H H I} \\
\times\left(\left(N T P E D_{\text {human }} \div\right.\right. & P R C) \times\left(M H F T_{\text {Hands }} \div D M F E_{\text {humans }}\right)+N T P_{L S 1} \\
& \left.\times L S A A H \times P M C_{L S 1-\text { Hands }}\right) \\
\div\left(\left(N E C E D_{\text {hands }} \div\right.\right. & P R C) \times\left(M H F T_{\text {Hands }} \div D M F E_{\text {humans }}+N E C_{L S 1}\right. \\
& \left.\times L S A A H \times P M C_{L S 1-\text { Hands }}\right)\end{aligned}$ & $\begin{array}{l}\text { CFU/two } \\
\text { hands }\end{array}$ \\
\hline
\end{tabular}

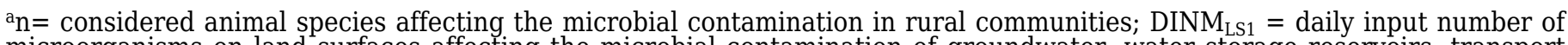
microorganisms on land surfaces affecting the microbial contamination of groundwater, water storage reservoirs, transport containers and hands $(\mathrm{CFU} / \mathrm{m} 2) ; \mathrm{PAD}_{\mathrm{LS} 1 \mathrm{n}}=$ percentage of animals defecating on land surfaces affecting the microbial contamination of groundwater, water storage reservoirs, transport containers and hands $(\%)$; $\mathrm{NMED}_{\mathrm{n}}=\mathrm{number}$ of microorganisms excreted per day (CFU); $\mathrm{AC}=$ area of communities; $\mathrm{DINM}_{\mathrm{LS} 2}=$ daily input number of microorganisms on land surfaces affecting the microbial contamination of surface waters $(\mathrm{CFU})$; $\mathrm{PAD}_{\mathrm{LS} 2 \mathrm{n}}=$ percentage of animals defecating on land surfaces affecting the microbial contamination of surface waters (\%); DINM $_{\mathrm{SK}}=$ daily input number of microorganisms in soakaways effluent $\left(\mathrm{CFU} /\right.$ per system); $\mathrm{PAD}_{\mathrm{SKn}}=$ percentage of animals defecating in soakaways $(\%)$; $\mathrm{NoH}=$ number of households present in rural communities; $\mathrm{RM}_{\mathrm{SK}}=$ assumed reduction of microorganisms within soakaways $(\%)$; $\mathrm{PH}_{\mathrm{SK}}=$ proportion of households presenting soakaways; $\mathrm{RF}_{\mathrm{SKI}}=$ assumed reduction of microorganisms due to intervention on sanitation $(\log 10 \mathrm{CFU}) ; \mathrm{NTP}_{\text {Hands }}=$ number of target pathogens $\left(\mathrm{CFU} /\right.$ two hands); $\mathrm{NEC}_{\text {Hands }}=$ number of $\mathrm{E}$. coli $(\mathrm{CFU} /$ two hands); $\mathrm{RF}_{\mathrm{HHI}}=$ reduction factor for hand hygiene intervention; $\mathrm{NTPED}_{\text {human }}=$ number of target pathogens excreted per day by humans (CFU); NECED human = number of E. coli excreted per day by humans (CFU); PRC = population of rural communities; MHFT $_{\text {Hands }}=$ mass of human faeces transferred to hands (g); DMFE $_{\text {humans }}=$ daily mass of faeces excreted by humans $(\mathrm{g})$; $\mathrm{NTP}_{\mathrm{LS} 1}=$ number of target pathogens on land surfaces affecting the microbial contamination of groundwater, water storage reservoirs, transport containers and hands $(\mathrm{CFU} / \mathrm{m} 2)$; $\mathrm{NECP}_{\mathrm{LS} 1}=$ number of $\mathrm{E}$. coli on land surfaces affecting the microbial contamination of groundwater, water storage reservoirs, transport containers and hands (CFU/m2); LSAAH = land surface area affecting hands contamination $(\mathrm{m} 2) ; \mathrm{PMC}_{\mathrm{LS1} \text {-Hands }}=$ proportion of microbial contribution from land surface (LS1) to hands (\%).

C. Microbial concentrations in drinking water sources 
Table A2. Formulas to estimate the number of E. coli and target pathogens in water sources

\begin{tabular}{|c|c|c|}
\hline Water source & Formula $^{a}$ & Unit \\
\hline Harvested rainwater & $\begin{array}{c}D I N M_{\text {roof }}=\left(\sum_{n=1}^{9}\left(P A D_{\text {Roof }_{n}} \times N M E D_{n}\right) \div N o H\right) \\
\quad \times\left(\sum_{m=1}^{5}\left(P D P E_{m} \times P M C P E_{\text {Roof }_{m}}\right) \div N D Y\right)\end{array}$ & CFU \\
\hline Surface water & $\begin{array}{c}\operatorname{DICM}_{S W} \\
=\left(\left(D I N M_{L S 2}\left(\sum_{m=1}^{5}\left(P D P E_{m} \times P M C P E_{S W_{m}}\right) \div N D Y+\right.\right.\right. \\
\left.\left.\sum_{n=1}^{9}\left(P A D_{S W_{n}} \times N M E D_{n}\right)\right)\right) \div V_{S W} \div 10\end{array}$ & CFU/100 mL \\
\hline Groundwater & $\begin{array}{c}D I C M_{G W}=\left(D I N M_{L S 1} \times A C \times P L S A G W \times R M T_{L S 1-G W} \times\right. \\
\left.\sum_{m=1}^{5} P D P E_{m}+D I N M_{S K} \times R T_{S K-G W}\right) \div V_{G W} \div 10\end{array}$ & CFU/100 mL \\
\hline Desalinated water & $D I C M_{D W}=\left(D I N M_{\text {Hands }} \times P M C_{\text {Hands }-D W S R}\right) \div V_{D W S S} \div 10$ & CFU/100 mL \\
\hline
\end{tabular}

${ }^{a} \mathrm{n}=$ considered animal species affecting the microbial contamination in rural communities; $\mathrm{m}=\mathrm{range}$ of accumulated precipitation depth in twenty-four hours (\%); DINM ${ }_{\text {roof }}=$ daily input number of microorganisms in roof run-off (CFU); $\mathrm{PAD}_{\mathrm{Roof}_{\mathrm{n}}}=$ percentage of animals defecating on the roof area (\%); $\mathrm{NMDE}_{\mathrm{n}}=$ number of microorganisms excreted per day $(\mathrm{CFU}) ; \mathrm{NoH}=$ number of households present in rural communities; $^{\text {PDPE }} \mathrm{n}_{\mathrm{n}}=$ proportion of days with precipitation events (\%); $\mathrm{PMCREr}_{\mathrm{m}}=$ proportion of microorganisms carried with roof runoff with precipitation events (\%); NDY = number of days in a year; DICM $_{\mathrm{Sw}}=$ daily input concentration of microorganisms in surface water $(\mathrm{CFU} / 100 \mathrm{~mL}) ; \mathrm{DINM}_{\mathrm{LS} 2}=$ daily input number of microorganisms on land surfaces affecting the microbial contamination of surface water (CFU); $\mathrm{PDPE}_{\mathrm{m}}=$ proportion of days with precipitation events (\%); $\mathrm{PMCPE}_{\mathrm{SW}_{\mathrm{m}}}$ proportion of microorganisms carried in run-off with precipitation events $(\%) ; \mathrm{PAD}_{\mathrm{SW}_{\mathrm{n}}}=$ percentage of animals defecating directly into surface waters (\%); DICM $\mathrm{GW}_{\mathrm{G}}=$ daily input concentration of microorganisms in groundwater $(\mathrm{CFU} / 100 \mathrm{~mL}) ; \mathrm{DINM}_{\mathrm{LS} 1}=$ daily input number of microorganisms on land surfaces affecting the microbial contamination of groundwater, water storage reservoirs, transport containers and hands (CFU/m2); DINM $_{\mathrm{SK}}=$ daily input number of microorganisms in soakaways' effluent (CFU/per system); $\mathrm{AC}=$ area of communities; PLSAGW = proportion of land surface affecting groundwater at the extraction points; $\mathrm{RMT}_{\mathrm{LS1}-\mathrm{GW}}=$ reduction of microorganisms during the transport of microbes from land surfaces to the groundwater reservoir $(\log 10 \mathrm{CFU}) ; \mathrm{RMT}_{\mathrm{SK}-\mathrm{GW}}=$ reduction of microorganisms during the transport of microbes from soakaways to the groundwater reservoir $(\log 10 \mathrm{CFU})$; $\mathrm{V}_{\mathrm{GW}}=$ volume of groundwater reservoir $(\mathrm{L}) ; \mathrm{DICM}_{\mathrm{DW}}=$ concentration of microorganisms in desalinated water at the collection point $(\mathrm{CFU} / 100 \mathrm{~mL})$; $\mathrm{DINM}_{\mathrm{Hands}}=$ daily input number of microorganisms on hands (CFU/ two hands); $\mathrm{PMC}_{\text {Hands-Dwss }}=$ assumed proportion of microbial contribution from hands to desalinated water storage reservoirs (\%); $\mathrm{V}_{\text {DwsS }}=$ volume of desalinated water storage reservoir (L). 
The hazardous events contributing to change in water quality from water storage reservoirs (WSR) to in-house drinking water storage containers (DWSC) along the water supply chain were assumed to be equal for every scenario variant created. The microbial load within WSR's was assumed to originate from hazardous events associated with microbial routes 10,11 and 13 and from water sources (T3 and T4, separately, or combined). Four hundred square meters of land around the WSR were assumed to contribute to the microbial contamination of it. A decrease of six $\log _{10}$ and seven $\log _{10}$ were assumed for the microbial contribution from land surfaces and soakaways, respectively. Finally, T3 was assumed to contribute to the microbial contamination of WSR's four times per year, as residents reported receiving water from these sources between one and four times per year. The combination of the formulas presented in Table A1 resulted in the formula F5, which was used to estimate the daily input concentration of microorganisms in WSR's.

The input concentrations of E. coli and TP at WSR's, estimated based on formula F5, was combined with the concentration of E. coli observed during the water quality monitoring program and the concentration of TP within WSR's used for the following steps of the QMRA and was estimated using formula F6.

$$
\begin{gathered}
D I C M_{W S R}=R F_{W T W S R 1} \times\left(D I N M_{L S 1} \times L S A A W S R \times P M C_{L S 1-W S R} \times\right. \\
\sum_{m=1}^{5}\left(P D P E_{m} \times P M C P E_{W S R_{m}}\right) \times R F_{F I}+D I N M_{S K} \times P M C_{S K-W S R}+N M_{H a n d s} \times P M C_{H a n d s-W S R} \\
+D I C M_{S W} \times V_{W S R} \times 10 \times P_{S W} \times P U_{T W}+D I C M_{G W} \times V_{W S R} \times 10 \times P_{G W} \times P U_{T W}+D I N M_{\text {roof }} \\
\left.\times P U_{H R R W}\right)(F 5)
\end{gathered}
$$

$D I C M_{W S S}=$ daily input concentration of microorganisms at water storage reservoirs (CFU/100 mL); RF WTWSRI $=$ reduction factor for water treatment at the water storage reservoir intervention $\left(\log _{10} \mathrm{CFU}\right) ; D I N M_{L S 1}=$ daily input number of microorganisms on land surfaces affecting the microbial contamination of groundwater, WSR, transport containers and hands $\left(\mathrm{CFU} / \mathrm{m}^{2}\right) ; D I N M_{S K}=$ daily input number of microorganisms in soakaways effluent (CFU); $N M_{\text {Hands }}=$ number of microorganisms on hands (CFU/two hands); DICM $M_{S W}=$ daily input concentration of microorganisms in surface water $(\mathrm{CFU} / 100 \mathrm{~mL}) ; D I C M_{G W}=$ daily input concentration of microorganisms in groundwater $(C F U / 100 \mathrm{~mL}) ; D I N M_{H R R W}=$ daily input number of microorganisms in harvested roof run-off rainwater; $P M C_{L S 1-W S R}=$ proportion of microbial contribution from land surfaces(\%); LSAAWSR = land surface area affecting water storage reservoirs $(\mathrm{m} 2)$; RFFI = reduction factor for fencing protection of water storage reservoirs intervention ( $\log 10 \mathrm{CFU})$; PMCSK-WSR = proportion of microbial contribution from soakaways to water storage reservoirs (\%); PMCHands-WSR = proportion of microbial contribution from hands to water storage reservoirs $(\%)$; PSW $=$ proportion of surface water $(\%)$; $\mathrm{PGW}=$ proportion of groundwater (\%); PUTW = proportion of users of tankered water (\%); PUHRRW = proportion of users of harvested roof run-off rainwater (\%)r; PDPEm = proportion of days with precipitation events (\%); PMCPESWRmproportion of microorganisms carried in run-off with precipitation events (\%) VWSR = volume of water storage reservoirs (L). 
The input concentrations of E. coli and TP at WSR's, estimated based on formula F5, was combined with the concentration of $E$. coli observed during the water quality monitoring program and the concentration of TP within WSR's used for the following steps of the QMRA and was estimated using formula F6:

$$
C T P_{W S R}=E C T P_{W S R} \times O C E C_{W S R} \div E C E C_{W S R}(F 6)
$$

\begin{abstract}
$\mathrm{CTP}_{\mathrm{WSR}}=$ concentration of target pathogens in water storage reservoirs $(\mathrm{CFU} / 100 \mathrm{~mL}) ; \mathrm{ECTP}_{\mathrm{WSR}}=$ estimated concentration of target pathogens in water storage reservoirs $(\mathrm{CFU} / 100 \mathrm{~mL})$; $\mathrm{OCEC}_{\mathrm{WSR}}=$ observed concentration of $\mathrm{E}$. coli in water storage reservoirs during field monitoring $(\mathrm{CFU} / 100 \mathrm{~mL}) ; \mathrm{ECEC}_{\mathrm{WSR}}=$ estimated concentration of $\mathrm{E}$. coli in water storage reservoirs $(\mathrm{CFU} / 100 \mathrm{~mL})$.
\end{abstract}

Transport containers (TC) (e.g. buckets) were assumed to receive microbial loads from hazardous events associated with microbial routes 12, 14, T6 and T7. One percent of microorganisms within an area of one square meter was assumed to contribute to the contamination of transport containers. Moreover, a reduction of two $\log _{10}$ for all microorganisms was assumed. Formula F7 was developed to estimate the concentration of target pathogens within inhouse drinking water storage containers, which were assumed to receive pathogens loads from microbial routes 16 and T8.

$$
\begin{gathered}
C T P_{D W S C}=R F_{D W S C I W T C} \times R F_{D W S C I W T F} \\
\times\left(N T P_{H a n d s} \times P M C_{H a n d s-D W S C}\right. \\
+\left(\left(D I N T P_{L S 1} \times L S A A T C \times P M C_{L S 1-T C} \times R F_{W H S I T C}+N T P_{\text {Hands }} \times P M C_{H a n d s-T C}+C T P_{D W}\right.\right. \\
\left.\left.\left.\times P U_{D W} \times V_{T C} \times 10+C T P_{W S R} \times P U_{W S R} \times V_{T C} \times 10\right) \div V_{T C} \div 10\right) \times V_{D W S C} \times 10\right) \div V_{D W S C} \\
\div 10(F 7)
\end{gathered}
$$

$C T P_{D W S C}=$ concentration of target pathogens at the in-house drinking water storage container; $N T P_{H a n d s}=$ number of target pathogens on hands (CFU/two hands); DINTP $P_{L S 1}=$ daily input number of target pathogens on land surfaces affecting the microbial contamination of groundwater, WSR, transport containers and hands $\left(\mathrm{CFU} / \mathrm{m}^{2}\right) ; C T P_{D W}=$ concentration of target pathogens in desalinated water at the collection point $(\mathrm{CFU} / 100 \mathrm{~mL}) ; C T P_{W S R}=$ concentration of target pathogens at water storage reservoirs $(\mathrm{CFU} / 100 \mathrm{~mL}) ; R F_{\text {DWSIWTC }}=$ reduction factor for water treatment at the in-house drinking water containers intervention through chlorination $\left(\log _{10} \mathrm{CFU}\right) ; R F_{\text {DWSCIWTF }}=$ reduction factor for water treatment at the in-house drinking water container intervention through filtration $\left(\log _{10} \mathrm{CFU}\right)$; $R F_{\text {WHSITC }}=$ reduction factor for safe handling and storage of drinking water intervention affecting the contamination of transport containers (\%); $P M C_{L S 1-T C}=$ proportion of microorganisms' contribution from land surfaces (LS1) to transport containers (\%); $P M C_{\text {Hands-TC }}=$ proportion of microorganisms' contribution from hands to transport containers (\%); $P M C_{\text {Hands-DWSC }}=$ proportion of microorganism contribution from hands to inhouse drinking water storage containers (\%); $P U_{D W}=$ proportion of users of desalinated water $(\%) ; P U_{W S S}=$ proportion of users of water from the water storage reservoirs (\%); $V_{T C}=$ volume of transport containers (L); $V_{D W S C}=$ volume of in-house drinking water storage containers (L); LSAATC = land surface area affecting transport containers. 


\section{References}

Antwi-Agyei, P., Biran, A., Peasey, A., Bruce, J. and Ensink, J. (2016). A faecal exposure assessment of farm workers in Accra, Ghana: a cross sectional study. BMC Public Health. 16(587), pp. 1-13.

Center for Advancing Microbial Risk Assessment (CAMRA) (2015). Dose Response [Online]: http://qmrawiki.canr.msu.edu/index.php/ Dose_Response [Accessed 15 February 2016].

Leak, E., Abla, M., Meschke, J.S., Jackson, C., Pogreba-Brown, K. and Eltholth, M.M. (2016). Case study: norovirus in drinking water [http://qmrawiki.canr.msu.edu/index.php/Case_Study:_Norovirus_in_Drinking_Water]. Center for Advancing Microbial Risk Assessment (CAMRA).

McCullough, M.C. and Eisele, C.W. (1951). Experimental human salmonellosis II: immunity studies following experimental illness with salmonella meleagridis and salmonella anatum. The Journal of Immunology. 66(5), pp. 595-608.

Pickering, A.J., Boehm, A.B., Mwanjali, M. and Davis, J. (2010). Efficacy of Waterless Hand Hygiene Compared with Handwashing with Soap: A Field Study in Dar es Salaam, Tanzania. The American Journal of Tropical Medicine and Hygiene. 82(2), pp. 270-278.

Rendtorff, R.C. (1953). The experimental transmission of human intestinal protozoan parasites. Oxford Journals. 59, pp. 209-220.

World Health Organization (WHO) (2017). Diarrhoeal disease. Key Facts. http://www.who.int/news-room/factsheets/detail/diarrhoeal-disease.

Williams, B.L., Florez, Y. and Pettygrove, S. (2001). Inter- and intra-ethnic variation in water intake, contact, and source estimates among Tuscon residents: Implications for exposure analysis. Journal of Exposure Analysis and Environmental Epidemiology. 11, pp. 510-521. 